\title{
Syntheses of Silatranyl- and Germatranyl-uridines
}

\author{
Chad M. Rink, ${ }^{\dagger}$ Matthew C. Mauck, ${ }^{\dagger}$ Irfan Asif, ${ }^{\dagger}$ \\ Michael E. Pitzer, ${ }^{\S}$ and Edward E. Fenlon ${ }^{\star, \S}$ \\ Department of Chemistry, Xavier University, 3800 Victory Parkway, \\ Cincinnati, Ohio 45207; Department of Chemistry, Franklin \& Marshall \\ College, PO Box 3003, Lancaster, Pennsylvania, 17604
}

edward.fenlon@fandm.edu

\section{Supporting Information}

\section{EXPERIMENTAL}

\section{General}

All reagents were ACS reagent quality, purchased from Aldrich, and used without further purification unless otherwise noted. Uridine was purchased from Chem-Impex International, Wood Dale, IL. 5'-O-DMTr-oxazolino-uridine (3) and 5'-O-DMTr-2'amino-2'deoxyuridine (10) were prepared according to McGee's procedure. ${ }^{21}$ All reactions were stirred with a magnetic stir bar and conducted under a dry nitrogen or argon atmosphere. Analytical thin layer chromatography (TLC) was performed on 0.2 $\mathrm{mm}$ silica plastic coated sheets (Selecto Scientific) with $\mathrm{F}_{254}$ indicator. Preparative TLC was performed on $1.0 \mathrm{~mm}$ silica coated glass plates (Whatman) with $F_{254}$ indicator. Flash chromatography was performed on Selecto Scientific 32-63 um silica gel.

NMR spectra were obtained at the following frequencies: ${ }^{1} \mathrm{H}(300 \mathrm{MHz})$ and ${ }^{13} \mathrm{C}$ $(75.5 \mathrm{MHz})$, and ${ }^{29} \mathrm{Si}(99.3 \mathrm{MHz})$ unless noted otherwise. Spectra were obtained in chloroform- $d\left(\mathrm{CDCl}_{3}\right)$ unless otherwise noted. Chemical shifts are reported in parts per million (ppm) and coupling constants are reported in hertz $(\mathrm{Hz}) .{ }^{1} \mathrm{H}$ and ${ }^{29} \mathrm{Si}$ spectra in $\mathrm{CDCl}_{3}$ were referenced to tetramethylsilane $(\mathrm{TMS}=0.0 \mathrm{ppm})$ as an internal standard. ${ }^{13} \mathrm{C}$ NMR spectra in $\mathrm{CDCl}_{3}$ were referenced to the solvent peak at $77.0 \mathrm{ppm} .{ }^{1} \mathrm{H}$ NMR spectra in $\mathrm{D}_{2} \mathrm{O}$ were referenced to the $\mathrm{HOD}$ peak at $4.65 \mathrm{ppm}$. IR spectra were obtained as a thin film and the absorptions are reported in $\mathrm{cm}^{-1}$. Mass spectrometry was performed at the University of Illinois School of Chemical Sciences, Urbana, IL on a PE Biosystems Voyager, Micromass 70-VSE-B or a Micromass ZAB-SE spectrometer. Mass spectra are reported in Daltons with a relative intensity to a base peak (base $=$ 100). Melting points were measured on a Mel-Temp melting point apparatus and are uncorrected. 


\section{Procedures}

1-\{6-[Bis-(4-methoxy-phenyl)-phenyl-methoxymethyl]-2-trichloromethyl3a,4,6,6a-tetrahydro-furo[3,4-d] oxazol-4-yl\}-3-methyl-1H-pyrimidine-2,4dione (4).

DMF-DMA procedure. A mixture of $3(2.5 \mathrm{~g}, 3.7 \mathrm{mmol})$, dimethyl formamidedimethyl acetal (DMF-DMA) $(0.740 \mathrm{~mL}, 5.5 \mathrm{mmol})$, and toluene $(2.5 \mathrm{~mL})$ was heated at $100{ }^{\circ} \mathrm{C}$ for $5 \mathrm{~h}$, then concentrated under reduced pressure. The resulting product was purified on silica gel ( $20 \rightarrow 50 \%$ ethyl acetate/hexanes) to afford $2.41 \mathrm{~g}(95 \%)$ of 4 as a yellow powder: $\mathrm{mp} 126-127^{\circ} \mathrm{C} ;{ }^{1} \mathrm{H}$ NMR $(500 \mathrm{MHz}) \delta 7.41(\mathrm{~d}, \mathrm{~J}=7.3,2 \mathrm{H}) 7.32-7.20$ $(\mathrm{m}, 8 \mathrm{H}), 6.80(\mathrm{~m}, 4 \mathrm{H}), 5.71(\mathrm{~d}, J=8.3,1 \mathrm{H}), 5.70(\mathrm{~s}, 1 \mathrm{H}), 5.43(\mathrm{dd}, J=8.6, J=4.2$, $1 \mathrm{H}), 5.15(\mathrm{dd}, J=8.5, J=2.2,1 \mathrm{H}), 4.35(\mathrm{~m}, 1 \mathrm{H}), 3.78(\mathrm{~s}, 6 \mathrm{H}), 3.60(\mathrm{dd}, J=10.2, J=$ $7.1,1 \mathrm{H}), 3.39$ (dd, $J=10.2, J=3.4,1 \mathrm{H}), 3.17(\mathrm{~s}, 3 \mathrm{H}) ;{ }^{13} \mathrm{C}$ NMR $(125.65 \mathrm{MHz}) \delta 163.2$, $162.5,158.59,158.56,150.5,144.4,140.6,135.7,135.4,130.1,130.0,128.1,127.8$, $126.9,113.09,113.07,102.1,96.4,87.4,87.0,86.5,77.6,55.2,27.4$; IR 2917, 1714, $1671,1509,1251$; FAB mass spec $386.1\left(\mathrm{M}^{+}+1\right), 303.1\left(\mathrm{DMT}^{+}, 100\right)$.

$\mathbf{N a H}$, dimethyl sulfate procedure. To a solution of $3(3.0 \mathrm{~g}, 4.46 \mathrm{mmol})$ in THF (85mL) was added $\mathrm{NaH}(197 \mathrm{mg}, 4.91 \mathrm{mmol})$. Effervescence was observed after the addition of $\mathrm{NaH}$ and the solution appeared yellowish and homogenous. The reaction was stirred at room temperature for $1 \mathrm{~h}$. Dimethyl sulfate $(0.69 \mathrm{~g}, 0.51 \mathrm{~mL}, 5.35$ $\mathrm{mmol}$ ) was then added and the solution was stirred for $1.5 \mathrm{~h}$ at room temperature. The solution was then concentrated under reduced pressure and the resulting viscous mixture was purified by flash column chromatography on silica gel $(20 \rightarrow 50 \%$ ethyl acetate/hexanes) to yield $2.5 \mathrm{~g}(82 \%)$ of $\mathbf{4}$ as a yellow powder identical to the material prepared by the DMF-DMA procedure above.

\section{1-\{3-Amino-5-[bis-(4-methoxy-phenyl)-phenyl-methoxymethyl]-4- hydroxy-tetrahydro-furan-2-yl\}-3-methyl-1H-pyrimidine-2,4-dione} Oxazoline-uridine $4(1.0 \mathrm{~g}, 2.6 \mathrm{mmol})$, ethanol/water $(2: 1,40 \mathrm{~mL})$ and $\mathrm{Cs}_{2} \mathrm{CO}_{3}(949 \mathrm{mg}$, $2.91 \mathrm{mmol}$ ) were combined and the yellowish mixture was heated at $100{ }^{\circ} \mathrm{C}$ for 5 days. The mixture was concentrated under reduced pressure, dissolved in $\mathrm{CH}_{2} \mathrm{Cl}_{2}$ and washed with aqueous $\mathrm{NH}_{4} \mathrm{Cl}$, deionized $\mathrm{H}_{2} \mathrm{O}$, and brine. The organic layer was concentrated under reduced pressure. The crude product was purified by flash chromatography (3\% $\mathrm{CH}_{3} \mathrm{OH} / \mathrm{CH}_{2} \mathrm{Cl}_{2}$ ) to yield $696 \mathrm{mg}(87 \%)$ of $\mathbf{5}$ as a tan powder: $\mathrm{mp} 99-100{ }^{\circ} \mathrm{C} ;{ }^{1} \mathrm{H}$ NMR $\delta$ $7.70(\mathrm{~d}, J=8.2,1 \mathrm{H}), 7.39-7.23(\mathrm{~m}, 9 \mathrm{H}), 6.84(\mathrm{~d}, J=8.5,4 \mathrm{H}), 5.91(\mathrm{~d}, J=5.8,1 \mathrm{H})$, $5.51(\mathrm{~d}, J=8.2,1 \mathrm{H}), 4.24-4.16(\mathrm{~m}, 2 \mathrm{H}), 3.80(\mathrm{~s}, 6 \mathrm{H}), 3.61(\mathrm{t}, J=5.8,1 \mathrm{H}), 3.47-3.43$ $(\mathrm{m}, 2 \mathrm{H}), 3.33(\mathrm{~s}, 3 \mathrm{H}) ;{ }^{13} \mathrm{C}$ NMR $\delta 162.7,158.6,151.8,144.2,137.5,135.2,135.1$, 130.0, 127.97, 127.95, 127.1, 113.2, 101.6, 90.6, 87.0, 85.3, 71.4, 63.2, 59.6, 55.2, 27.6; IR 3369, 2931, 2837, 1706, 1659, 1508, 1250; FAB mass spec $582.2\left(\mathrm{M}^{+} \mathrm{Na}^{+}, 9\right)$, $560.2(\mathrm{M}+1,8), 303.1\left(\mathrm{DMT}^{+}, 100\right)$. 
Preparation of the ethylene oxide stock solution. (CAUTION: ethylene oxide is volatile (bp $11^{\circ} \mathrm{C}$ ), highly toxic, and a suspected carcinogen. A fume hood should be used at all times.) A tared heavy walled glass storage vessel (Ace glass \#5555-33) was cooled in an ice water bath and ethylene oxide gas (Aldrich) was transferred through a trap and into the vessel via tubing capped with a glass pipette. After $\sim 10$ min the gas was shut off, the tubing removed, and vessel was capped with a Teflon ${ }^{\circ}$ bushing with a Kalrez ${ }^{\circledR}$ O-ring. The mass of the condensed liquid ethylene oxide was obtained and the appropriate amount of methanol was then added. The stock solution was stored in a refrigerator in the capped heavy walled vessel.

1-\{3-[Bis-(2-hydroxy-ethyl)-amino]-5-[bis-(4-methoxy-phenyl)-phenylmethoxymethyl]-4-hydroxy-tetrahydro-furan-2-yl\}-3-methyl-1H-pyrimidine2,4-dione (6). To a glass pressure vessel was added 5 (230 mg, $0.411 \mathrm{mmol})$ and 2 $M$ ethylene oxide in methanol (CAUTION: ethylene oxide is volatile (bp $11^{\circ} \mathrm{C}$ ), highly toxic, and a suspected carcinogen) $(12 \mathrm{~mL}, 24 \mathrm{mmol}, 58 \mathrm{eq})$. The vessel was sealed with a Teflon $\AA$ bushing fitted with a Kalrez $\AA$ o-ring and heated in an oil bath at $130{ }^{\circ} \mathrm{C}$ for $48 \mathrm{~h}$ (CAUTION: a blast shield should be used). The vessel was cooled in an ice bath and opened. The solvent and excess ethylene oxide were then removed under reduced pressure. The resulting clear oil was purified by preparatory-plate silica gel chromatography (methanol/ethyl acetate/dichloromethane 1:5:5) to yield $202 \mathrm{mg}$ (76\%) of 6 as a yellow crystalline solid: mp 90-91 ${ }^{\circ} \mathrm{C} ;{ }^{1} \mathrm{H}$ NMR $\delta 7.89(\mathrm{~d}, J=8.2,1 \mathrm{H})$, 7.39-7.23 (m, 9H), $6.83(\mathrm{~d}, J=8.8,4 \mathrm{H}), 6.30(\mathrm{~d}, J=4.9,1 \mathrm{H}), 5.37(\mathrm{~d}, J=8.2,1 \mathrm{H})$, $4.45(\mathrm{t}, J=5.9,1 \mathrm{H}), 4.10(\mathrm{t}, J=2.5,1 \mathrm{H}), 3.79(\mathrm{~s}, 6 \mathrm{H}), 3.73-3.51(\mathrm{~m}, 7 \mathrm{H}), 3.4(\mathrm{~m}$, $2 \mathrm{H}), 3.31(\mathrm{~s}, 3 \mathrm{H}), 3.00(\mathrm{~m}, 4 \mathrm{H}) ;{ }^{13} \mathrm{C}$ NMR $\delta 162.8,158.70,158.68,151.1,144.3,137.8$, 135.3, 135.0, 130.14, 130.11, 128.1, 128.0, 127.2, 113.3, 101.9, 87.1, 86.0, 85.1, 70.8, $69.6,62.9,60.3,55.3,54.4,27.7$; FAB mass spec $670.3\left(\mathrm{M}+\mathrm{Na}^{+}, 21\right), 648.3(\mathrm{M}+1$, 5), $303.1\left(\mathrm{DMT}^{+}, 100\right)$.

1-\{5-[Bis-(4-methoxy-phenyl)-phenyl-methoxymethyl]-8-ethoxy-4,7,9,14tetraoxa-1-aza-8-sila-tricyclo[6.3.3.02,6]tetradec-3-yl\}-3-methyl-1H-

pyrimidine-2,4-dione (7). Triol $6(100 \mathrm{mg}, 0.15 \mathrm{mmol})$, ortho-dichlorobenzene (3.0 $\mathrm{mL}), \mathrm{Si}(\mathrm{OEt})_{4}(0.1 \mathrm{~mL}, 0.46 \mathrm{mmol})$, and $\mathrm{KOH}(10 \mathrm{mg}, 0.15 \mathrm{mmol})$ were heated at 130 ${ }^{\circ} \mathrm{C}$ for $2 \mathrm{~h}$. The crude product was concentrated under reduced pressure and purified using a silica gel plate $\left(77: 20: 3 \mathrm{CH}_{2} \mathrm{Cl}_{2}\right.$ :acetone: $\left.\mathrm{CH}_{3} \mathrm{OH}\right)$ to yield $79 \mathrm{mg}(71 \%)$ of 7 as a white powder: $\mathrm{mp} 151-153{ }^{\circ} \mathrm{C} ;{ }^{1} \mathrm{H}$ NMR $\delta 8.10(\mathrm{~d}, J=8.2,1 \mathrm{H}), 7.40-7.22(\mathrm{~m}, 9 \mathrm{H}), 6.84$ $(\mathrm{d}, J=8.8,4 \mathrm{H}), 6.14(\mathrm{~s}, 1 \mathrm{H}), 5.32(\mathrm{~d}, J=8.2,1 \mathrm{H}), 4.82(\mathrm{t}, J=8.5,1 \mathrm{H}), 4.10(\mathrm{~d}, J=$ $9.1,1 \mathrm{H}), 3.94(\mathrm{~m}, 3 \mathrm{H}), 3.80(\mathrm{~s}, 6 \mathrm{H}), 3.74(\mathrm{q}, J=7.1,2 \mathrm{H}), 3.58(\mathrm{~m}, 2 \mathrm{H}), 3.36(\mathrm{~m}, 2 \mathrm{H})$, $3.31(\mathrm{~s}, 3 \mathrm{H}), 3.12(\mathrm{dd}, J=12.3, J=3.0,1 \mathrm{H}), 2.92(\mathrm{~m}, 2 \mathrm{H}), 1.20(\mathrm{t}, J=7.1,3 \mathrm{H}) ;{ }^{13} \mathrm{C}$ NMR $\delta 162.47,162.46,158.73,158.71,158.7,151.0,144.1,136.8,135.17,135.15$, $134.90,134.87,130.5,130.13,130.08,128.1,128.0,127.2,113.29,113.27,101.7$, 87.06, 87.05, 86.8, 86.7, 70.21, 70.17, 68.7, 61.6, 58.8, 58.6, 58.5, 55.2, 52.8, 50.6, 27.38, 27.37, 18.2; ${ }^{29} \mathrm{Si}$ NMR $\delta-90.14$; FAB mass spec $740.3\left(\mathrm{M}+\mathrm{Na}^{+}, 38\right), 718.3(\mathrm{M}+$ $1,16), 303.1\left(\mathrm{DMT}^{+}, 100\right)$. 


\section{1-(8-Ethoxy-5-hydroxymethyl-4,7,9,14-tetraoxa-1-aza-8-sila-}

tricyclo[6.3.3.02,6]tetradec-3-yl)-3-methyl-1H-pyrimidine-2,4-dione (1).

Silatrane $7(65 \mathrm{mg}, 0.018 \mathrm{mmol})$, methanol $(5 \mathrm{~mL})$, and $\mathrm{K}-10$ clay (montmorillonite $\mathrm{K}$ 10) $(46 \mathrm{mg}$ ) were combined and stirred at room temp for $21 \mathrm{~h}$. The mixture was filtered through Celite and the Celite was washed with methanol. The mixture was concentrated under reduced pressure and purified on a silica gel plate $\left(5 \% \mathrm{CH}_{3} \mathrm{OH} /\right.$ $\mathrm{CH}_{2} \mathrm{Cl}_{2}$ ) to yield $22 \mathrm{mg}(60 \%)$ of $\mathbf{1}$ as a white powder: mp $190-191{ }^{\circ} \mathrm{C} ;{ }^{1} \mathrm{H}$ NMR $\left(\mathrm{D}_{2} \mathrm{O}\right) \delta$ $7.81(\mathrm{~d}, J=8.2,1 \mathrm{H}), 6.18(\mathrm{~s}, 1 \mathrm{H}), 5.80(\mathrm{~d}, J=8.2,1 \mathrm{H}), 4.41(\mathrm{t}, J=8.2,1 \mathrm{H}), 3.97-$ $3.50(\mathrm{~m}, 8 \mathrm{H}), 3.53(\mathrm{q}, J=7.0,2 \mathrm{H}), 3.20(\mathrm{~m}, 2 \mathrm{H}), 3.13(\mathrm{~s}, 3 \mathrm{H}), 2.98(\mathrm{t}, J=7.0,3 \mathrm{H})$; FAB mass spec 416.1 (M+1,10), 119.0(100) $438.1\left(\mathrm{M}+\mathrm{Na}^{+}, 2\right), 177.0(100)$.

1-\{5-[Bis-(4-methoxy-phenyl)-phenyl-methoxymethyl]-8-hydroxy-4,7,9,14tetraoxa-1-aza-8-germa-tricyclo[6.3.3.02,6]tetradec-3-yl\}-3-methyl-1H-

pyrimidine-2,4-dione (8). To a round bottom flask was added $\mathrm{GeO}_{2}(18 \mathrm{mg}, 0.17$ $\mathrm{mmol}, 1.1 \mathrm{eq})$ and water $(3.5 \mathrm{~mL})$. This mixture was heated in an oil bath at $95^{\circ} \mathrm{C}$ and then a mixture of triol $6(100 \mathrm{mg}, 0.16 \mathrm{mmol})$ in acetonitrile $(3.5 \mathrm{~mL})$ was injected into the flask. The reaction mixture was heated for $4 \mathrm{~h}$ and then concentrated under reduced pressure to afford $105 \mathrm{mg}(92 \%)$ of 8 as a white powder: $\mathrm{mp} 235-240{ }^{\circ} \mathrm{C}$ (dec.); ${ }^{1} \mathrm{H}$ NMR $\delta 8.04(\mathrm{~d}, J=8.2,1 \mathrm{H}), 7.40-7.15(\mathrm{~m}, 11 \mathrm{H}), 6.86-6.81(\mathrm{~m}, 7 \mathrm{H}), 6.17$ $(\mathrm{s}, 1 \mathrm{H}), 5.27(\mathrm{~d}, J=8.2,1 \mathrm{H}), 4.82(\mathrm{t}, J=8.7,1 \mathrm{H}), 4.12-3.92(\mathrm{~m}, 1 \mathrm{H}), 3.80(\mathrm{~s}, 6 \mathrm{H})$, 3.79-3.60 (m, 4H), $3.31(\mathrm{~s}, 3 \mathrm{H}) ;{ }^{13} \mathrm{C}$ NMR $\delta$ 162.8, 158.70, 158.68, 151.1, 144.3, 137.8, $135.3,135.0,130.14,130.1,128.14,128.0,127.2,113.3,101.9,87.1,86.0,85.1,70.8$, 69.6, 62.9, 60.3, 55.3, 54.4, 27.7; IR 3180, 3057, 2837, 1687, 1508, 1247, 826, 733,

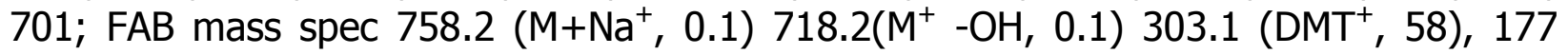
(100).

\section{1-(8-Hydroxy-5-hydroxymethyl-4,7,9,14-tetraoxa-1-aza-8-germa-} tricyclo[6.3.3.02,6] tetradec-3-yl)-3-methyl-1H-pyrimidine-2,4-dione (2). A mixture of 8 (59.6 mg, $0.081 \mathrm{mmol}$ ), K-10 clay (montmorillonite $\mathrm{K} 10)$ (35 mg), and distilled water $(3 \mathrm{~mL})$ was stirred at room temperature for $24 \mathrm{~h}$. The mixture was filtered through a pad of Celite and the filtrate was concentrated under reduced pressure. The resulting solid was then triturated with hexanes and dried under reduced pressure to give $17.6 \mathrm{mg}(51 \%)$ of 2 as a crystalline white solid: $\mathrm{mp} 245-250{ }^{\circ} \mathrm{C}$ (dec.); ${ }^{1} \mathrm{H}$ NMR $\left(\mathrm{D}_{2} \mathrm{O}, 500 \mathrm{MHz}\right) \delta 7.87(\mathrm{~d}, J=8.3,1 \mathrm{H}), 6.23(\mathrm{~d}, J=1.0,1 \mathrm{H}), 5.81(\mathrm{~d}, J$ $=8.3,1 \mathrm{H}), 4.43(\mathrm{t}, J=8.5,1 \mathrm{H}), 3.97-3.68(\mathrm{~m}, 7 \mathrm{H}), 3.53(\mathrm{dt}, J=11.5, J=3.9,1 \mathrm{H})$, $3.36(\mathrm{qd}, J=12.0, J=3.5,2 \mathrm{H}), 3.14(\mathrm{~s}, 3 \mathrm{H}), 3.00(\mathrm{~m}, 1 \mathrm{H}), 2.90(\mathrm{~m}, 1 \mathrm{H}) ;{ }^{13} \mathrm{C} \mathrm{NMR}$ $\left(\mathrm{D}_{2} \mathrm{O}, 125.7 \mathrm{MHz}\right) \delta 165.7,151.6,138.7,101.2,87.6,87.0,68.4,66.5,60.5,57.6,57.1$, 52.7, 51.0, 27.7; IR 3393 (br), 2950, 2900, 1698, 1653, 1616, 1473, 1097, 1064, 667; ESI mass spec $434.2\left(\mathrm{M}^{+}+1,51\right), 416.1(\mathrm{M}-\mathrm{OH}, 18), 346.3(100), 302.3$ (57). Molecular ion peaks show the expected germanium isotope pattern, see spectrum below. 


\section{COMPOUNDS NOT EXPLICITLY SHOWN IN THE PAPER}

If $\mathrm{N}-3$ remains unmethylated, it reacts with ethylene oxide:

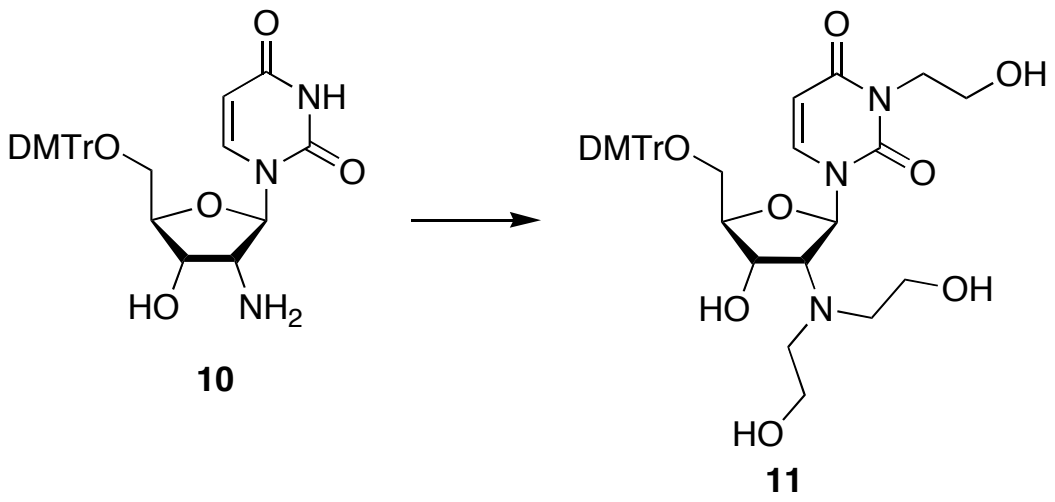

1-\{3-[Bis-(2-hydroxy-ethyl)-amino]-5-[bis-(4-methoxy-phenyl)-phenylmethoxymethyl]-4-hydroxy-tetrahydro-furan-2-yl\}-3-(2-hydroxy-ethyl)-1Hpyrimidine-2,4-dione (11). A solution of $\mathbf{1 0}(1.00 \mathrm{~g}, 1.8 \mathrm{mmol})$ and $1 \mathrm{M}$ ethylene oxide (CAUTION: ethylene oxide is volatile (bp $\sim 11^{\circ} \mathrm{C}$ ), highly toxic, and a suspected carcinogen.) in methanol ( $9 \mathrm{~mL}, 9 \mathrm{mmol})$ was stirred and heated at $135{ }^{\circ} \mathrm{C}$ for $2 \mathrm{~h}$ in a glass pressure vessel fitted with a Kalrez $®$ o-ring (CAUTION: a blast shield should be used). The vessel was cooled in an ice bath and opened. The solvent and excess ethylene oxide were then removed under reduced pressure. The rust colored oil was purified by column chromatography (methanol: ethyl acetate: dichloromethane; 1:10:10) to give $311 \mathrm{mg}(25 \%)$ of compound $\mathbf{1 1}$ as an off-white solid: $\mathrm{mp} 95^{\circ} \mathrm{C}$ (dec.); ${ }^{1} \mathrm{H}$ NMR $\delta 7.95(\mathrm{~d}, 1 \mathrm{H}), 7.30(\mathrm{~m}, 9 \mathrm{H}), 6.84(\mathrm{~d}, 4 \mathrm{H}), 6.31(\mathrm{~d}, 1 \mathrm{H}), 5.40(\mathrm{~d}, 1 \mathrm{H}), 4.45(\mathrm{~m}$, $1 \mathrm{H}), 4.21(\mathrm{~m}, 2 \mathrm{H}), 4.12(\mathrm{~m}, 1 \mathrm{H}), 3.84(\mathrm{~m}, 2 \mathrm{H}), 3.80(\mathrm{~s}, 6 \mathrm{H}), 3.66(\mathrm{~m}, 3 \mathrm{H}), 3.55(\mathrm{~m}$, $1 \mathrm{H}), 3.50(\mathrm{~m}, 2 \mathrm{H}), 3.00(\mathrm{~m}, 5 \mathrm{H}) ;{ }^{13} \mathrm{C}$ NMR $\delta 163.3,158.69,158.66,151.6,144.2$, $138.4,135.2,135.0,130.12,130.08,128.1,128.0,127.2,113.3,102.2,87.1,86.0$, 85.1, 71.0, 69.6, 63.0, 61.1, 60.1, 55.2, 54.0, 43.4; FAB MS $678.4\left(\mathrm{M}^{+}+1,8\right), 303.2$ $\left(\mathrm{DMT}^{+}, 100\right) 119$ (30). 


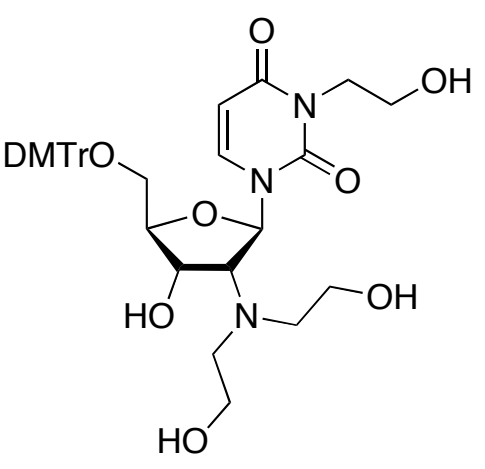

11

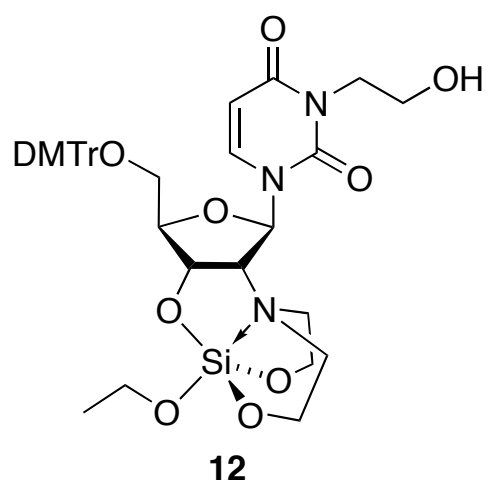

12

1-\{5-[Bis-(4-methoxy-phenyl)-phenyl-methoxymethyl]-8-ethoxy-4,7,9,14tetraoxa-1-aza-8-sila-tricyclo[6.3.3.0 ${ }^{2,6}$ ]tetradec-3-yl\}-3-(2-hydroxy-ethyl)1H-pyrimidine-2,4-dione (12). A solution of 11 (75 mg, $0.11 \mathrm{mmol})$, tetraethyl orthosilicate $(76 \mu \mathrm{L}, 0.48 \mathrm{mmol})$, DMF $(2 \mathrm{~mL})$, and potassium hydroxide $(3 \mathrm{mg}, 0.055$ $\mathrm{mmol}$ ) was stirred and heated at $100{ }^{\circ} \mathrm{C}$ for $20.5 \mathrm{~h}$. The mixture was concentrated on the vacuum pump while heating in a warm water bath. The residual was purified by preparative-plate TLC (7.5\% methanol in methylene chloride) to give $9 \mathrm{mg}(11 \%)$ of 12 as a white solid: ${ }^{1} \mathrm{H}$ NMR $\delta 8.06(\mathrm{~d}, J=8.1,1 \mathrm{H}), 7.39-7.26(\mathrm{~m}, 9 \mathrm{H}), 6.84(\mathrm{~d}, J=8.5$, $4 \mathrm{H}), 6.14(\mathrm{~s}, 1 \mathrm{H}), 5.31(\mathrm{~d}, J=8.1,1 \mathrm{H}), 4.84(\mathrm{t}, J=8.4,1 \mathrm{H}), 4.20-3.85(\mathrm{~m}, 8 \mathrm{H}), 3.802$ $(\mathrm{s}, 3 \mathrm{H}), 3.80(\mathrm{~s}, 3 \mathrm{H}), 3.74(\mathrm{q}, J=7.0,2 \mathrm{H}), 3.59(\mathrm{br} \mathrm{s}, 1 \mathrm{H}), 3.41-3.09(\mathrm{~m}, 3 \mathrm{H}), 1.20(\mathrm{t}$, $J=7.0,3 \mathrm{H})$; FAB MS $748.2\left(\mathrm{M}^{+}+1,4\right), 303.1\left(\mathrm{DMT}^{+}, 100\right)$.
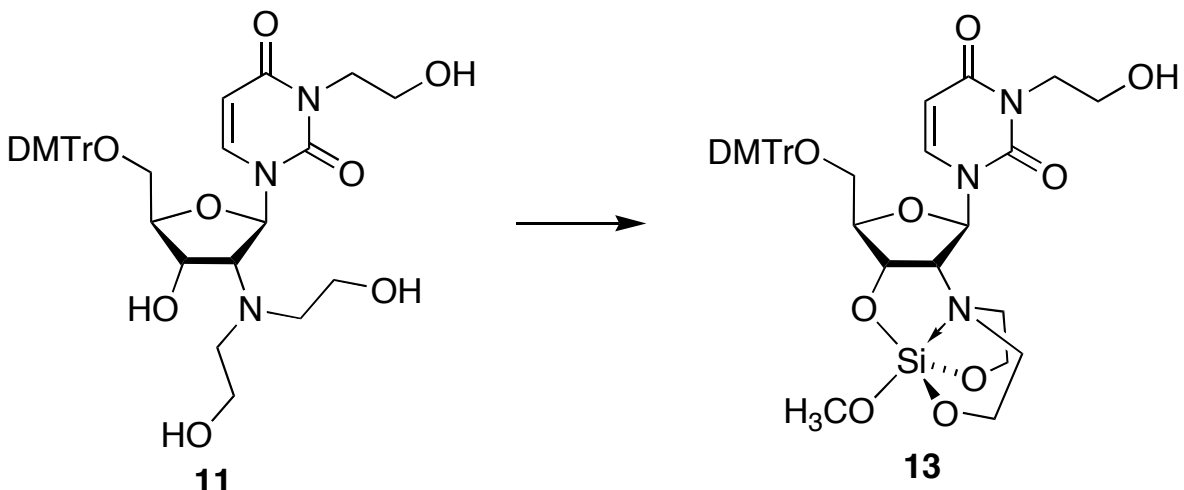

1-\{5-[Bis-(4-methoxy-phenyl)-phenyl-methoxymethyl]-8-methoxy-4,7,9,14tetraoxa-1-aza-8-sila-tricyclo[6.3.3.0 2,6] tetradec-3-yl\}-3-(2-hydroxy-ethyl)1H-pyrimidine-2,4-dione (13). A solution of 11 (200 mg, $0.295 \mathrm{mmol})$, tetramethyl orthosilicate $(2 \mathrm{~mL}, 13.6 \mathrm{mmol})$, and DMF $(2 \mathrm{~mL})$ was stirred and heated at $115{ }^{\circ} \mathrm{C}$ for 1 h. The mixture was concentrated under reduced pressure and then on the vacuum pump. The compound was purified by preparative-plate TLC $(5 \%$ ethanol in chloroform) to give $105 \mathrm{mg}(48 \%)$ of $\mathbf{1 3}$ as a white solid: ${ }^{1} \mathrm{H}$ NMR $\delta 8.05(\mathrm{~d}, J=8.2$, $1 \mathrm{H}), 7.38-7.25(\mathrm{~m}, 9 \mathrm{H}), 6.84(\mathrm{~d}, J=8.8,4 \mathrm{H}), 6.14(\mathrm{~s}, 1 \mathrm{H}), 5.30(\mathrm{~d}, J=8.2,1 \mathrm{H}), 4.83$ $(\mathrm{m}, 1 \mathrm{H}), 4.18(\mathrm{~m}, 2 \mathrm{H}), 4.15-3.88(\mathrm{~m}, 1 \mathrm{H}), 3.803(\mathrm{~s}, 3 \mathrm{H}), 3.80(\mathrm{~s}, 3 \mathrm{H}), 3.60(\mathrm{~m}, 1 \mathrm{H})$, $3.49(\mathrm{~s}, 3 \mathrm{H}), 3.40-3.30(\mathrm{~m}, 1 \mathrm{H}), 3.18-2.85(\mathrm{~m}, 4 \mathrm{H}), 2.33(\mathrm{~m}, 1 \mathrm{H}) ;{ }^{13} \mathrm{C}$ NMR $\delta 163.2$, $158.68,158.66,151.4,144.1,137.4,135.1,134.8,130.13,130.08,128.1,128.0$, 
127.2, 113.3, 101.8, 87.1, 86.84, 86.80, 70.0, 68.7, 61.5, 61.2, 58.6, 58.4, 55.2, 52.7, $51.0,50.6,43.3,31.5,22.6,14.1$. 


\section{SPECTRA}

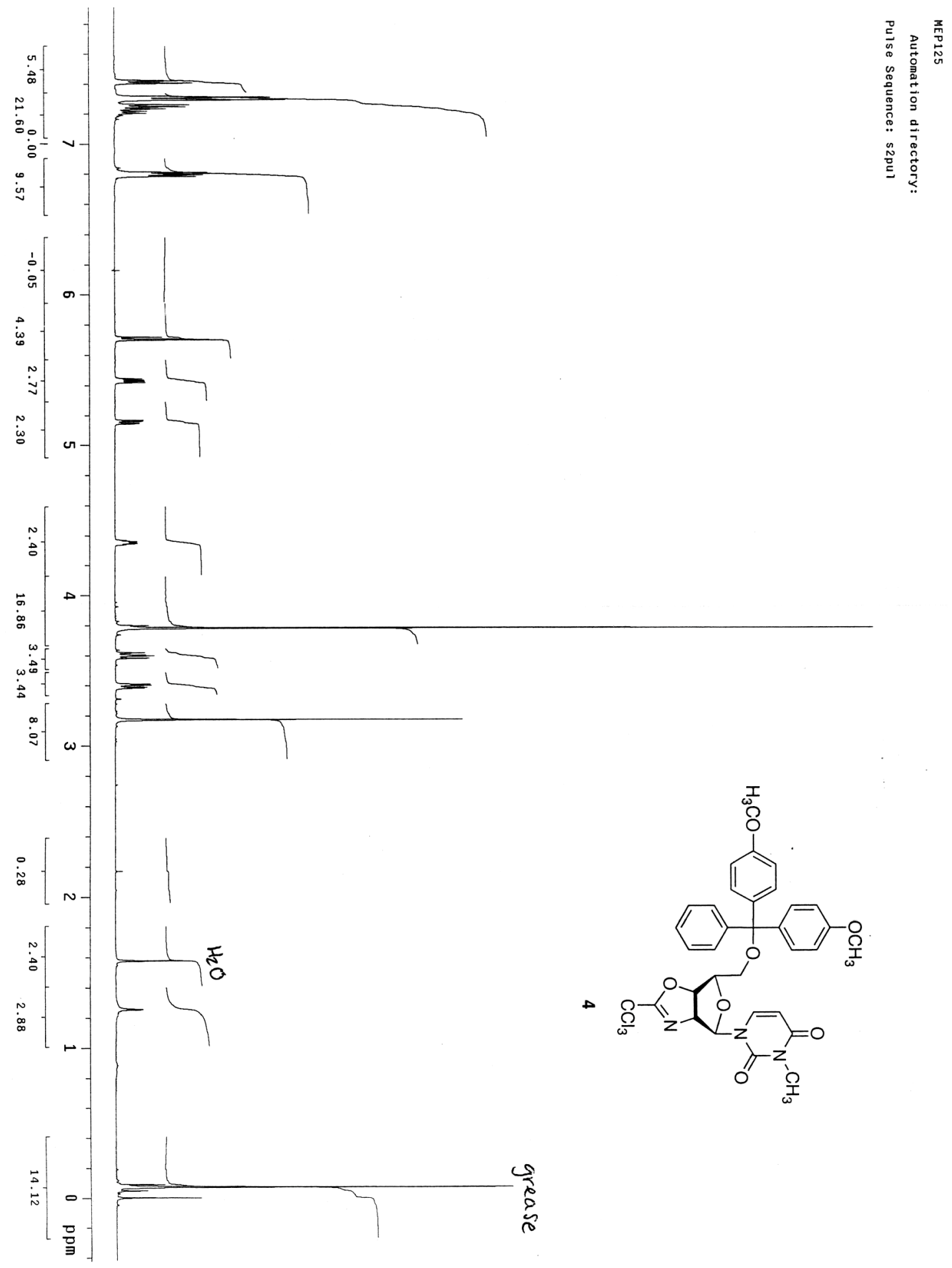




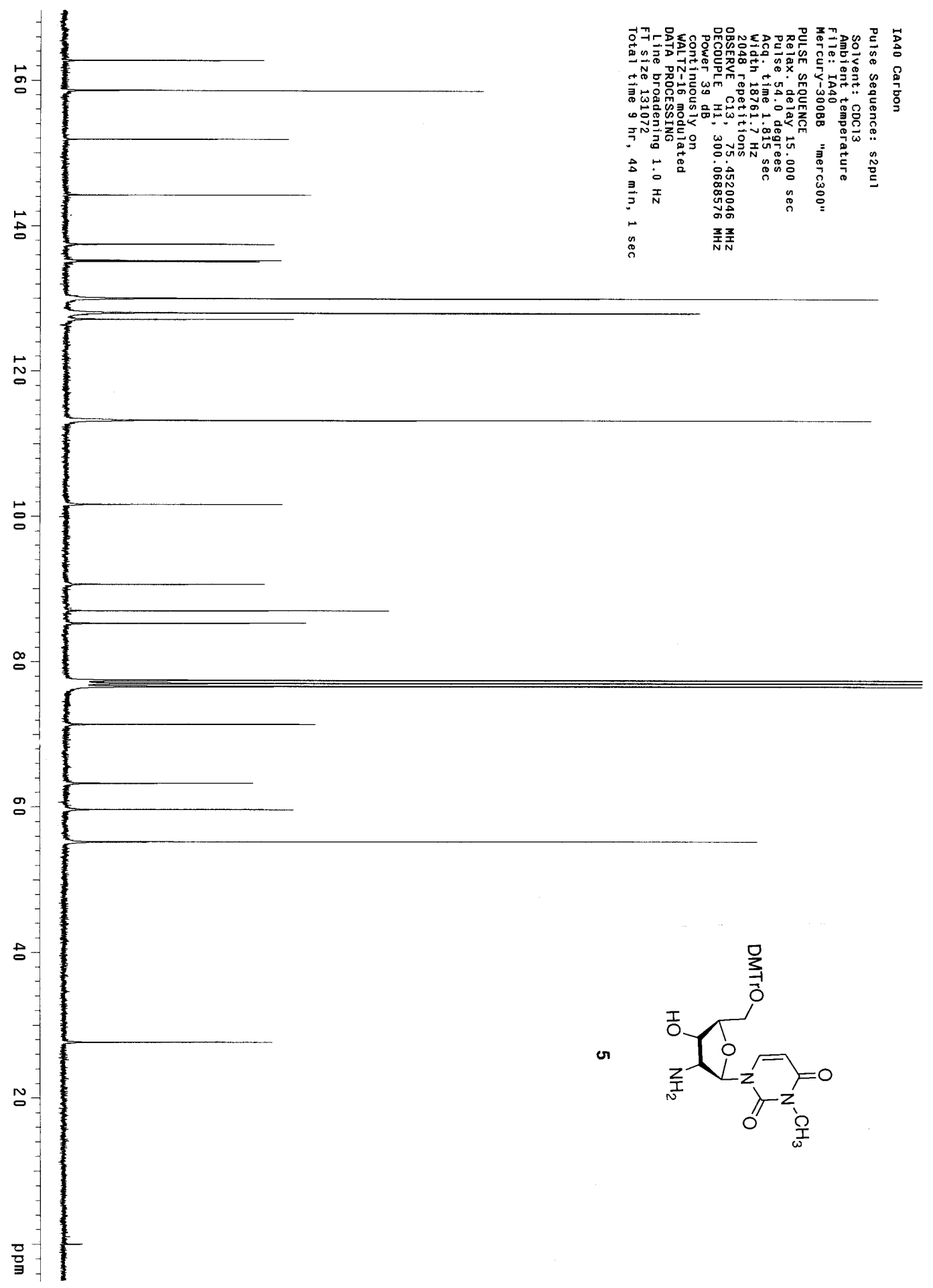




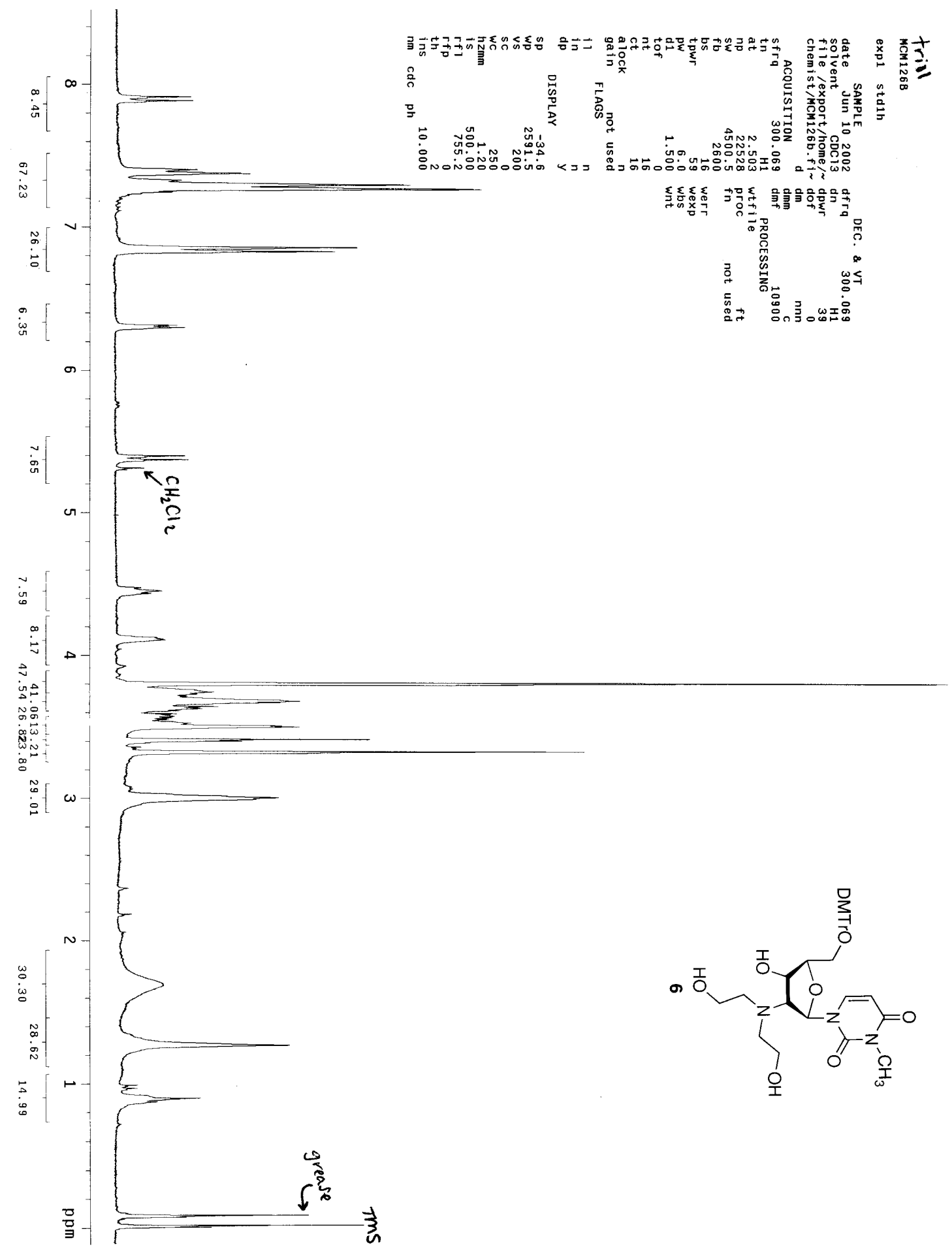




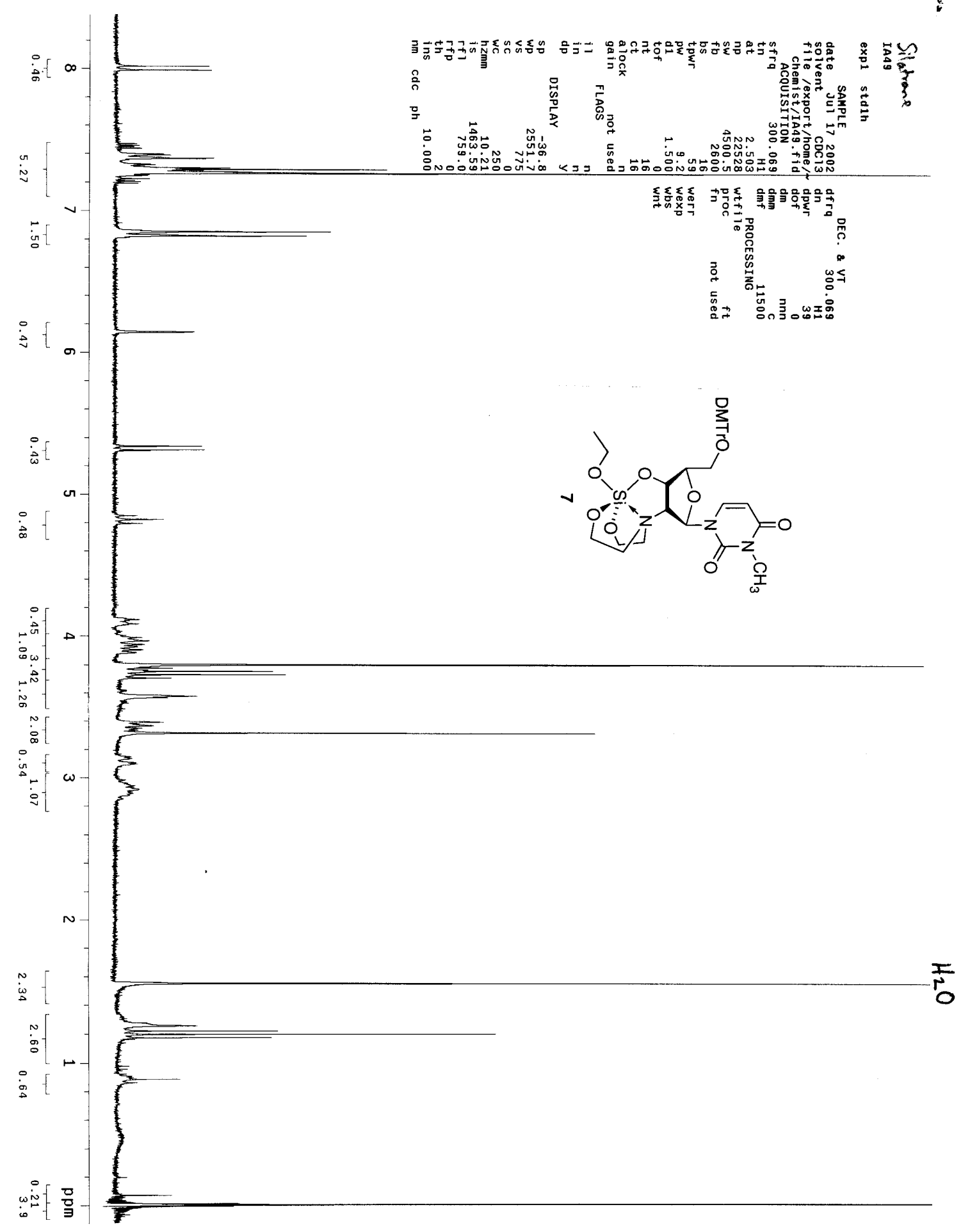




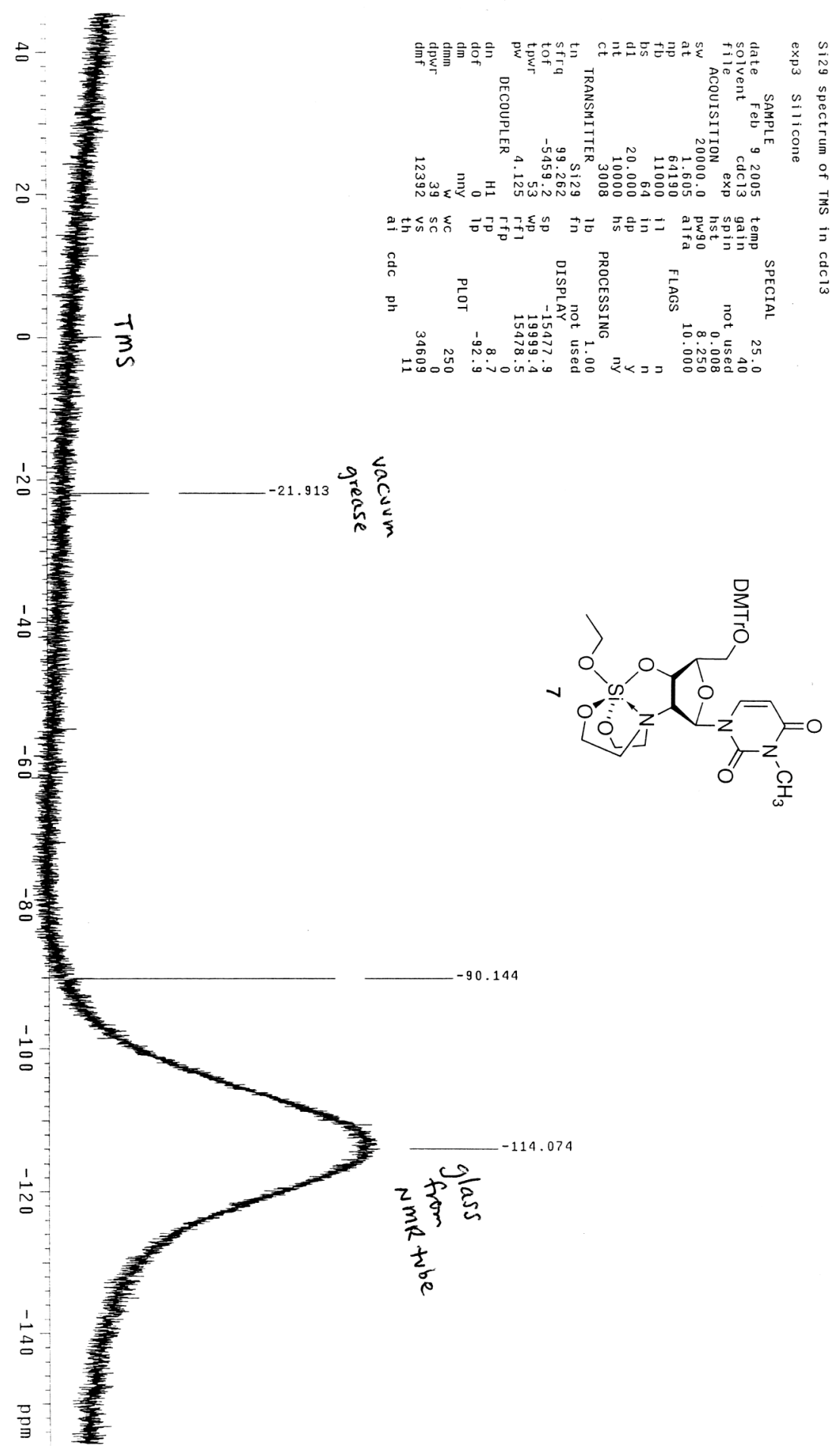

NOTE: A peak for vacuum grease was also prominent in the ${ }^{1} \mathrm{H}$ NMR spectrum of this sample. 


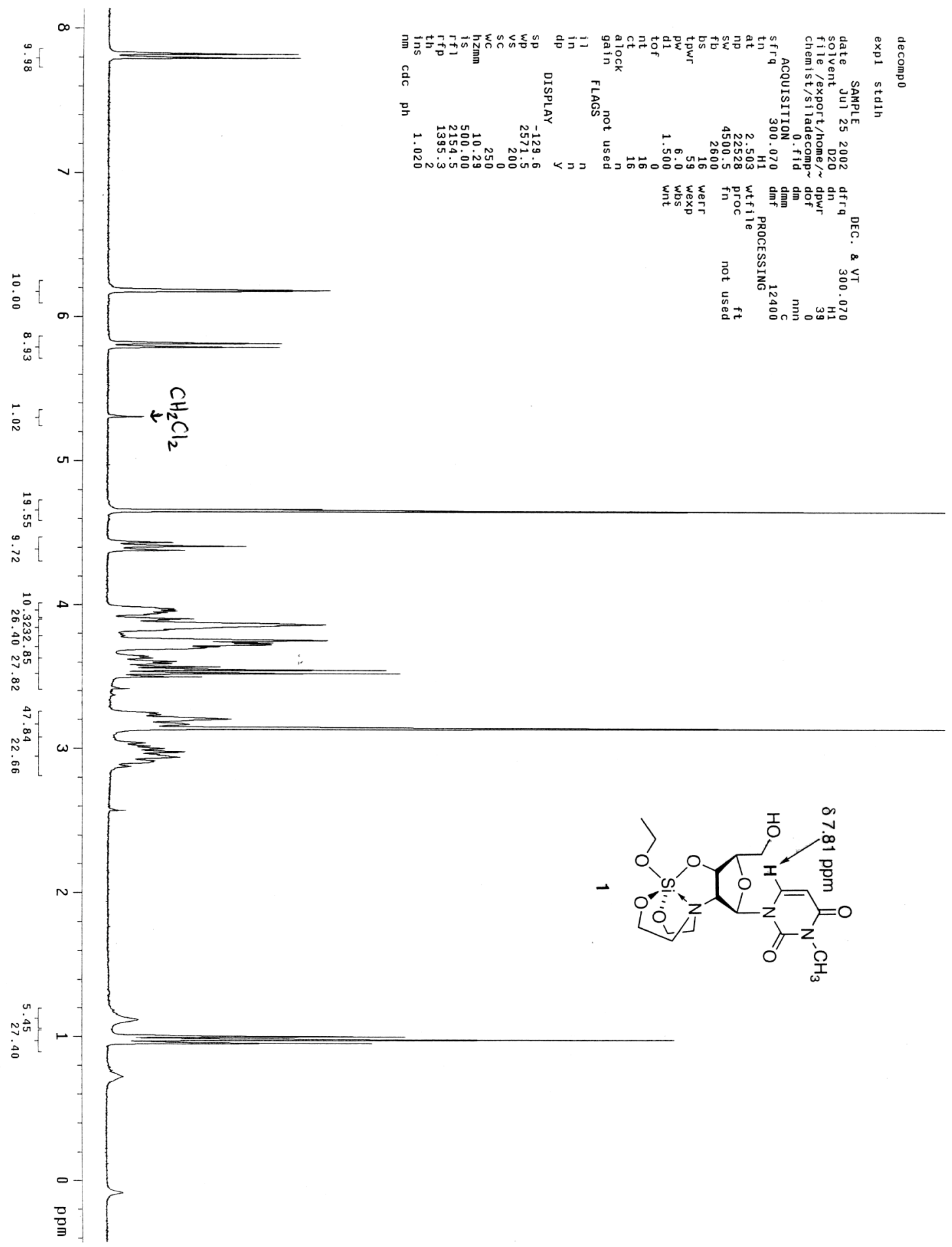




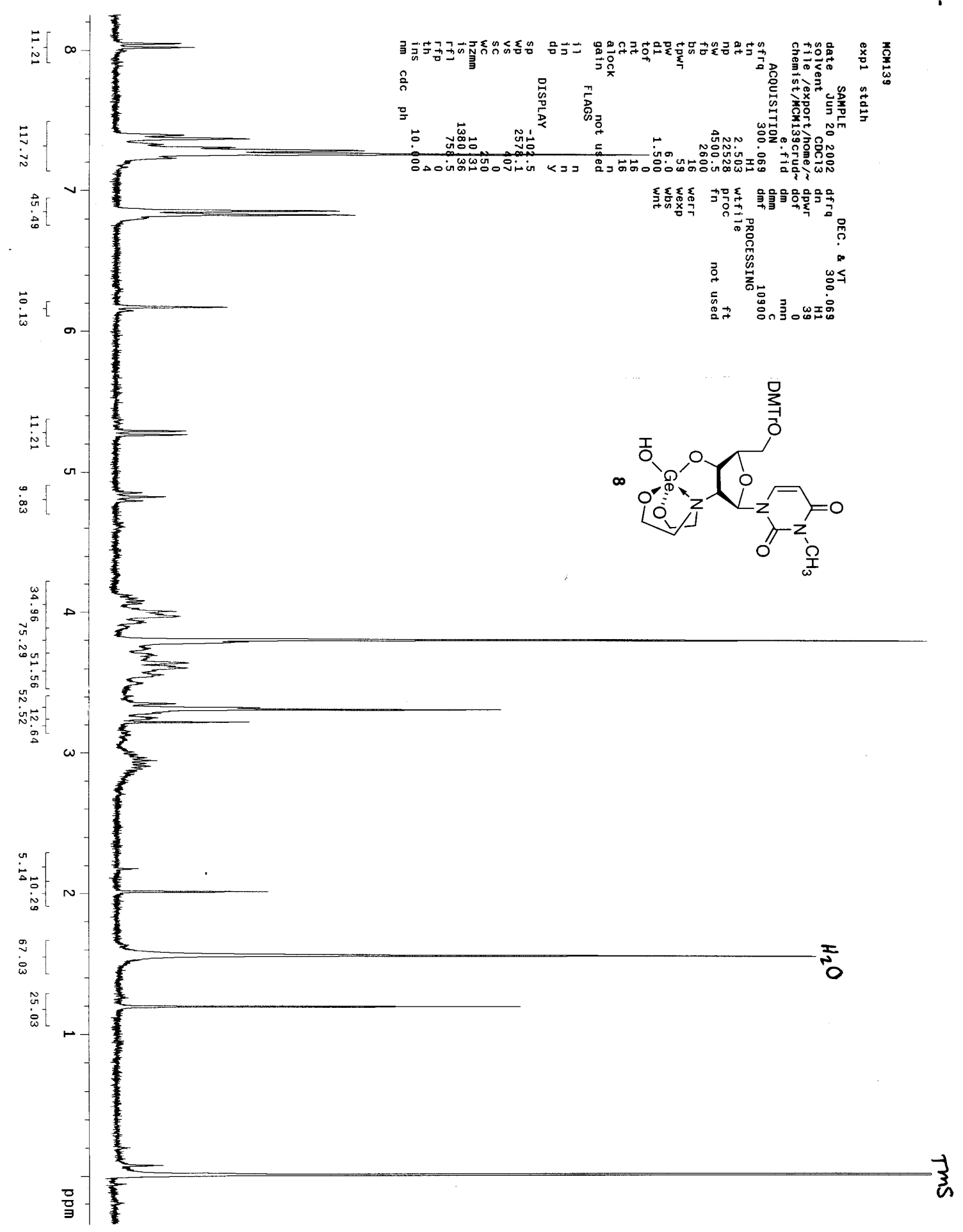




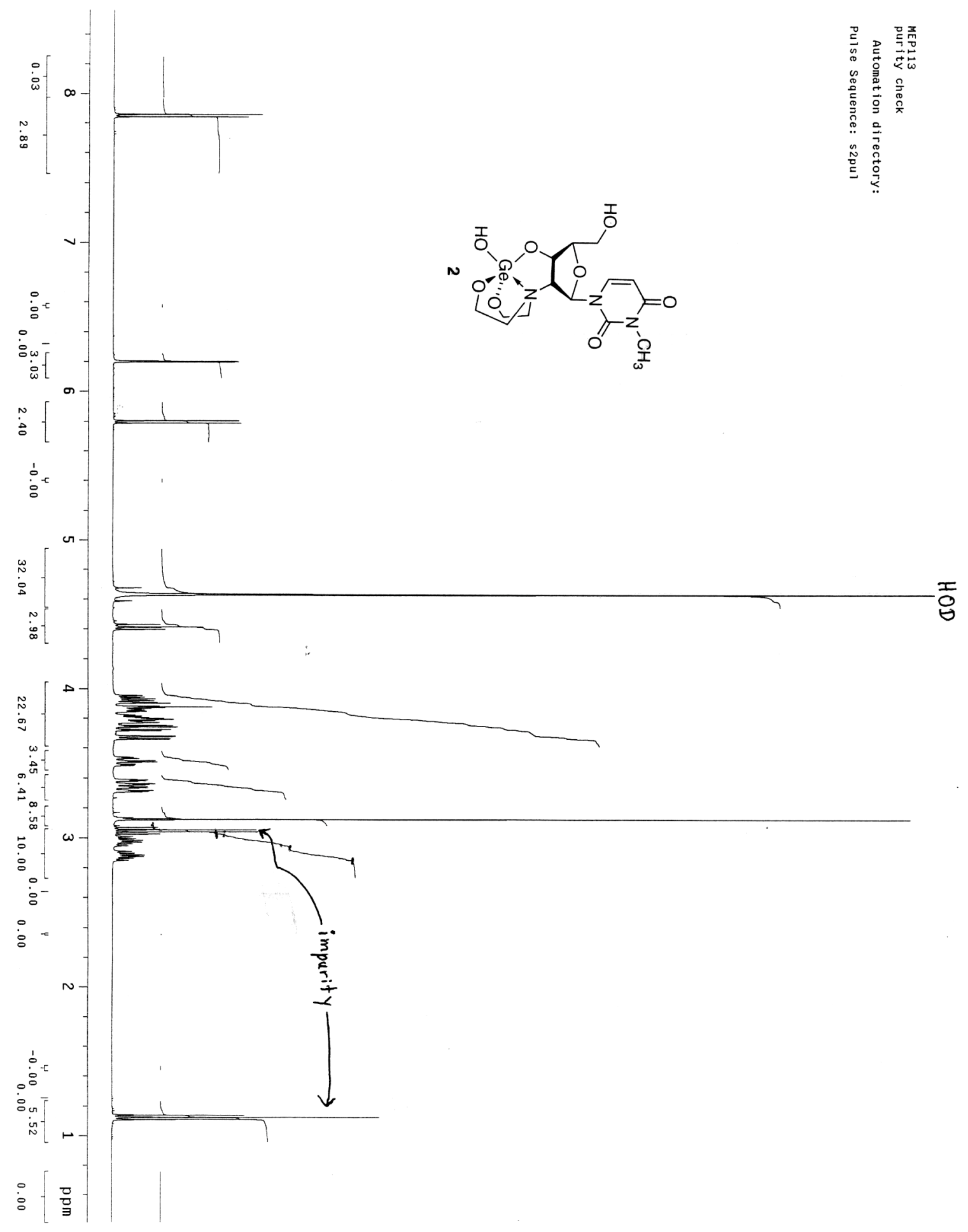




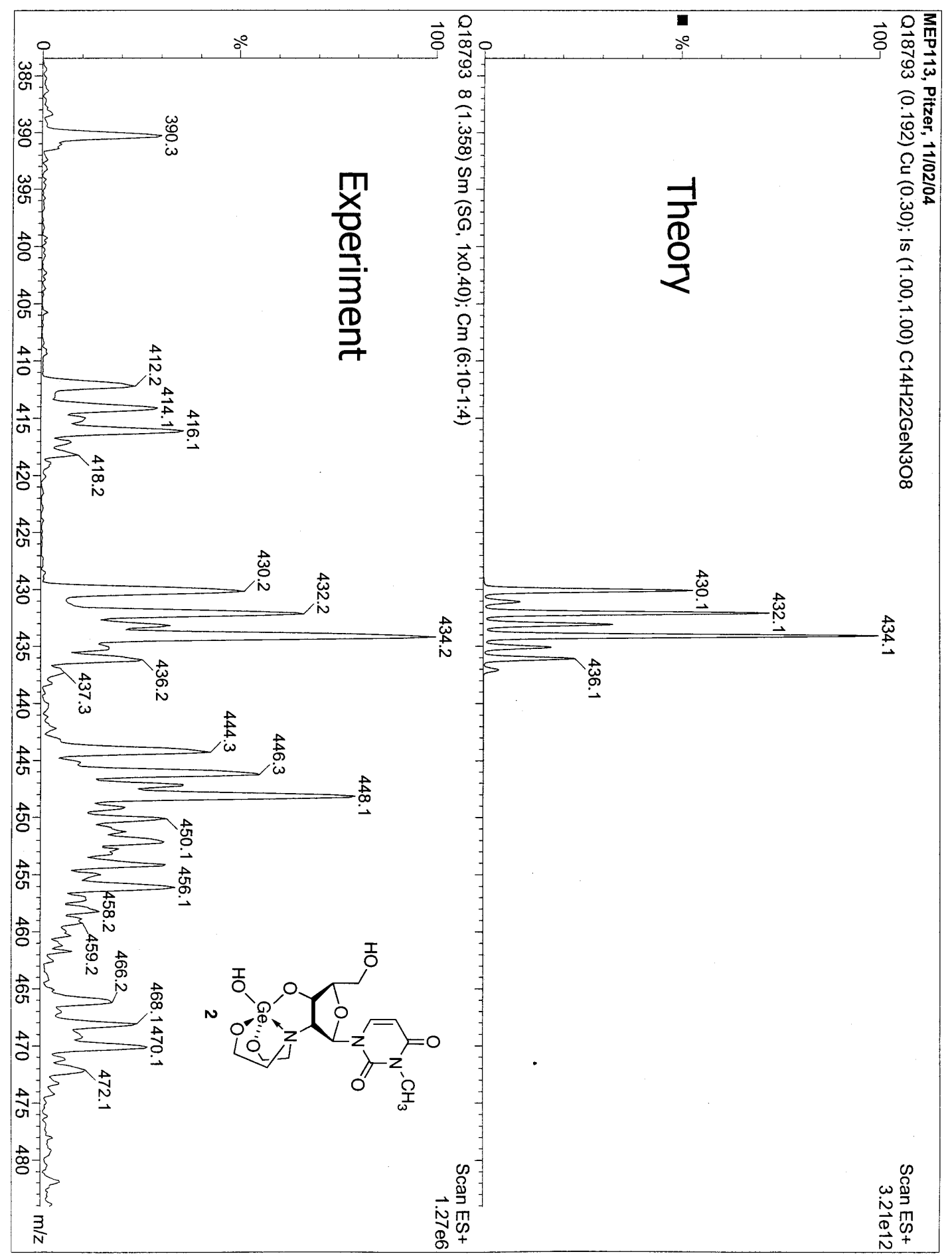

NOTE: The molecular ions around the peak at $m / z=434$ are the $M+1$ peaks for 2 and show the expected isotope pattern. The peak at $\mathrm{m} / \mathrm{z}=416$ is the $\mathrm{M}^{+}-\mathrm{OH}$ fragment. The peak at $\mathrm{m} / \mathrm{z}=448$ apparently is the $\mathrm{M}+1$ peak for the methoxygermatrane $\left(\mathrm{CH}_{3} \mathrm{O}-\mathrm{Ge}\right)$ derivative which may have formed in situ during the ESI-MS (there is no evidence for this impurity in the $500 \mathrm{MHz}{ }^{1} \mathrm{H}$ NMR spectrum, see above). The peak at $\mathrm{m} / \mathrm{z}=470$ apparently is the $\mathrm{M}+\mathrm{Na}^{+}$peak for this methoxygermatrane. 


\section{N-3 METHYLATION AND ATRANE STABILITY}

As briefly discussed in footnote 22 in the paper, if $\mathrm{N}-3$ is "deprotected" then anhydrouridine formation may occur, presumably by the mechanism shown in Scheme S1. For more information about anhydrouridine formation with leaving groups attached to $\mathrm{C2}^{\prime}$, see the Yung and Fox reference. ${ }^{22}$

\section{Scheme S1}

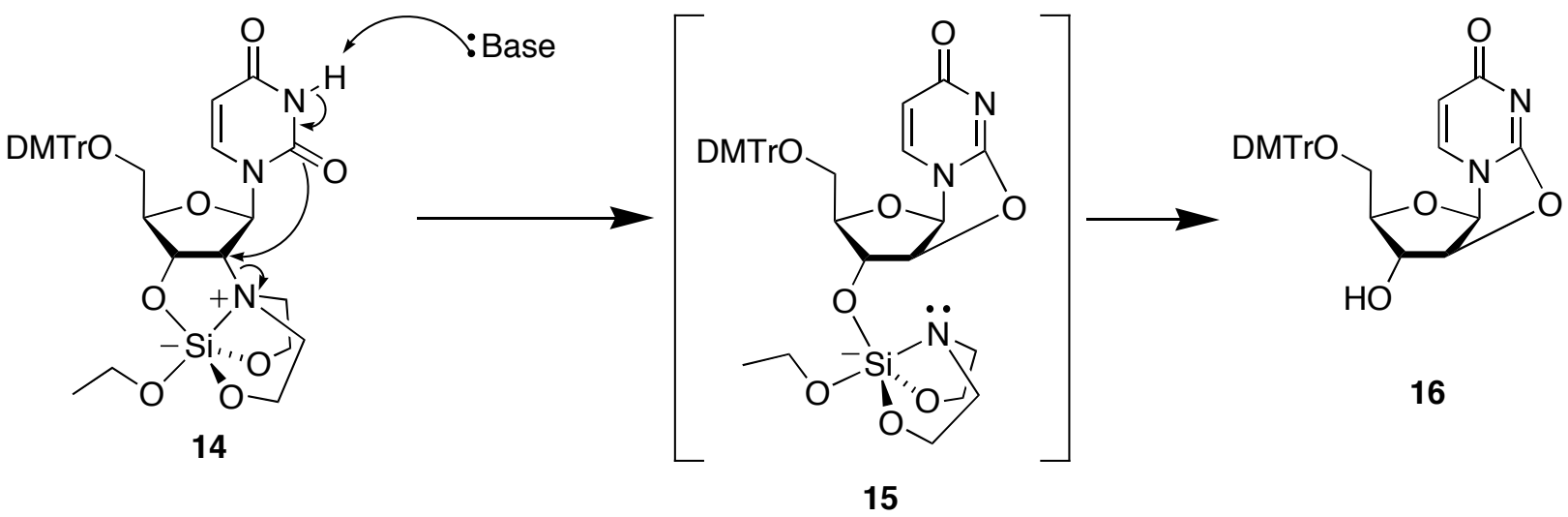

\section{AQUEOUS STABILITY STUDIES}

The aqueous stability of $\mathbf{1}$ and $\mathbf{2}$ was determined by monitoring a $\mathrm{D}_{2} \mathrm{O}$ solution by ${ }^{1} \mathrm{H}$ NMR spectroscopy.

A $25 \mathrm{mM}$ solution ( $10.3 \mathrm{mg}$ in $1 \mathrm{~mL} \mathrm{D}_{2} \mathrm{O}$ ) of silatranyl-uridine $\mathbf{1}$ was used for this experiment and the decrease in integration of the doublet for the $\mathrm{H}^{6}$-proton in $\mathbf{1}$ and the corresponding increase in the integration of the doublet for the same proton in uridine $\mathbf{9}$ were studied. Typical spectra of silatranyl-uridine $\mathbf{1}$ during the study are shown below, one at time zero, one before the half-life ( 5 day mark), and the last after the half-life (11 day mark). The methylene chloride solvent peak served as an internal reference.

A $41 \mathrm{mM}$ solution ( $17.6 \mathrm{mg}$ in $1 \mathrm{~mL} \mathrm{D}_{2} \mathrm{O}$ ) of germatranyl-uridine 2 was used for this experiment. Spectra $(200 \mathrm{MHz})$ of germatranyl-uridine $\mathbf{2}$ are shown below, one at time zero and the second three weeks later. In fact, a $500 \mathrm{MHz}$ spectrum (shown above) after 119 days at room temperature still shows pure germatranyl-uridine 2. NOTE: The triplet at $1.15 \mathrm{ppm}$ and the quartet at $3.08 \mathrm{ppm}$ (this peak is much better resolved at $500 \mathrm{MHz}$ ) are from an unknown semi-volatile impurity. After prolonged periods (e.g., $14 \mathrm{~h}$ ) under high vacuum the intensity of this ethyl containing impurity decreases relative to the peaks for $\mathbf{2}$ (compare the last spectra below at $500 \mathrm{MHz}$ to the $500 \mathrm{MHz}$ spectra of $\mathbf{2}$ above). 


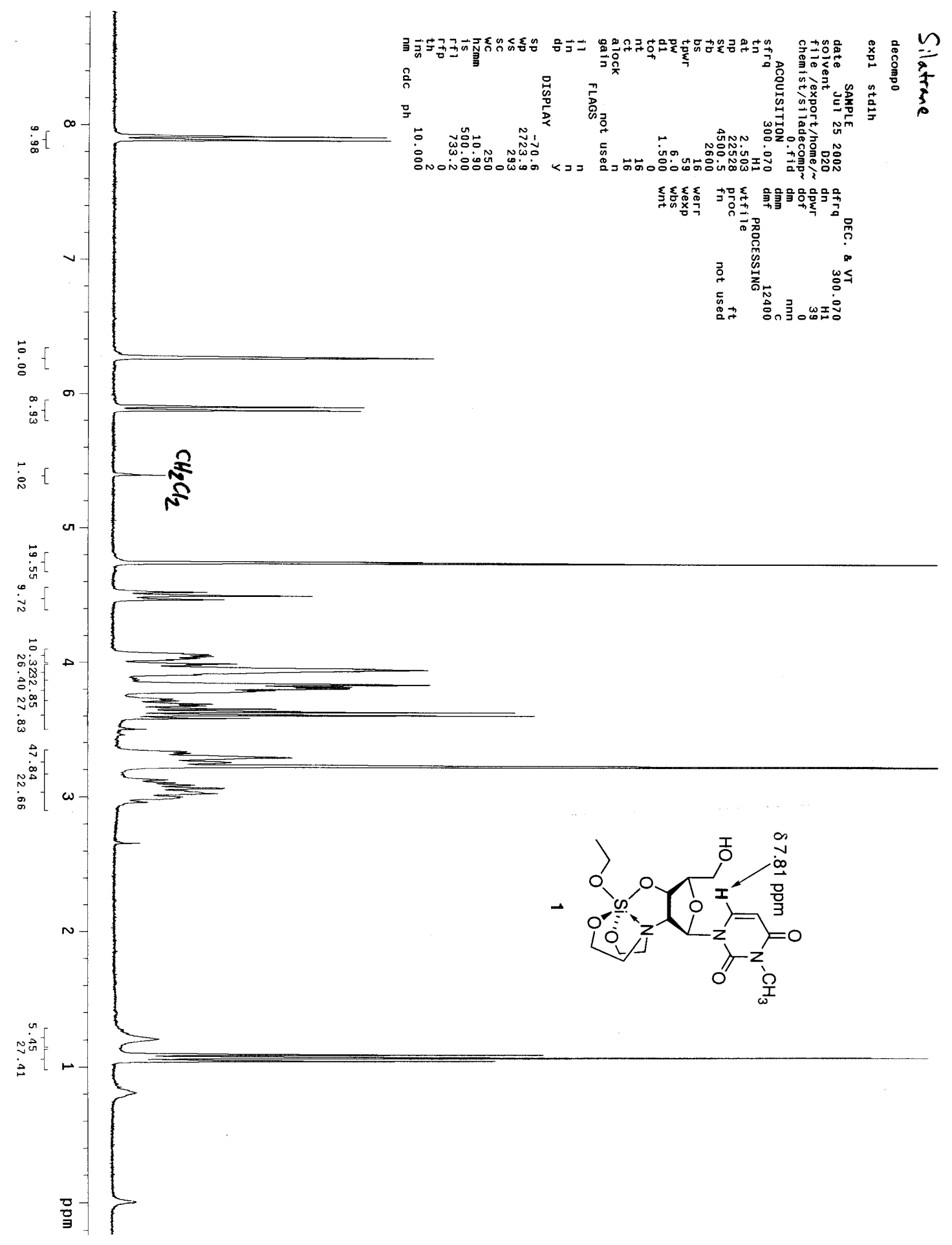




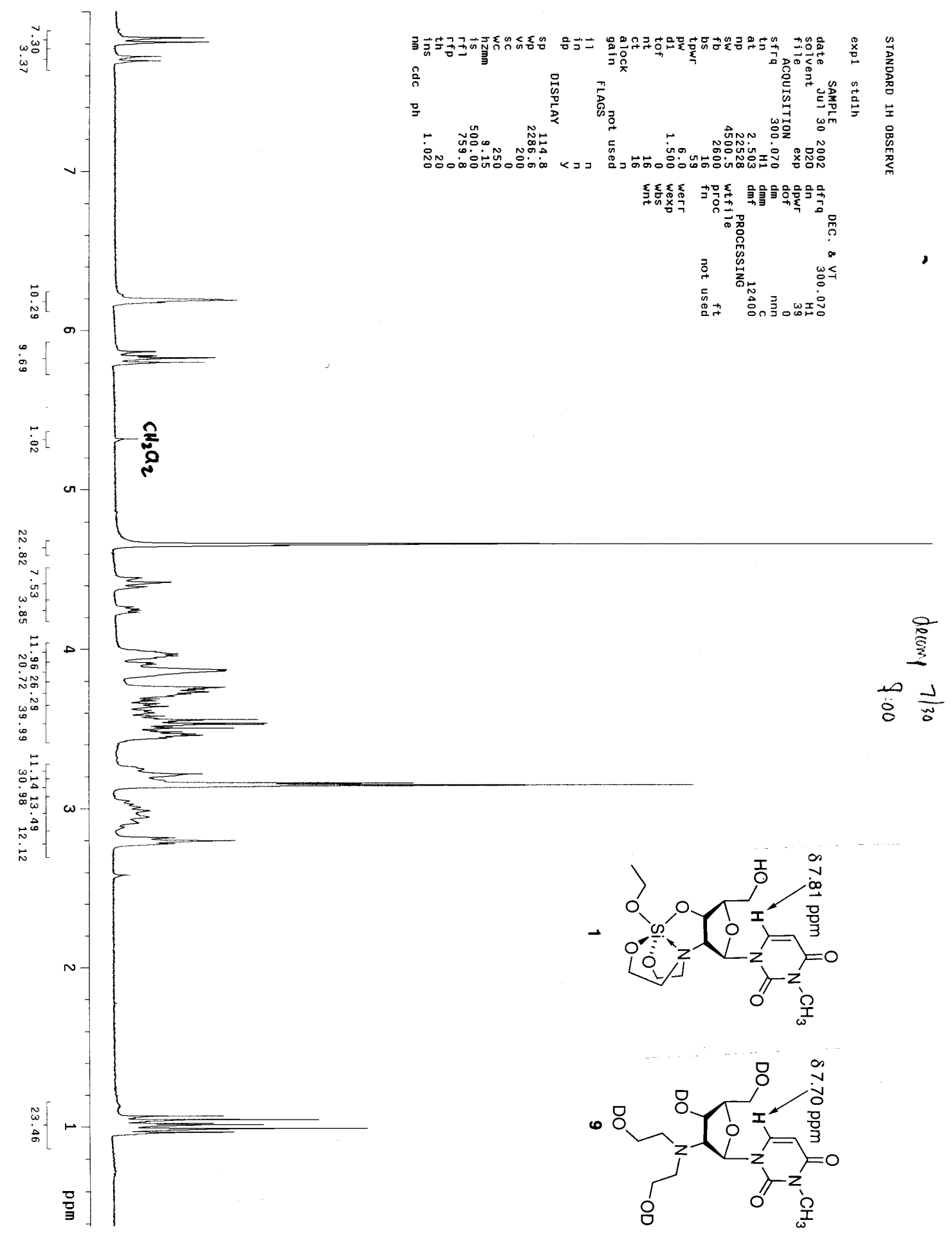




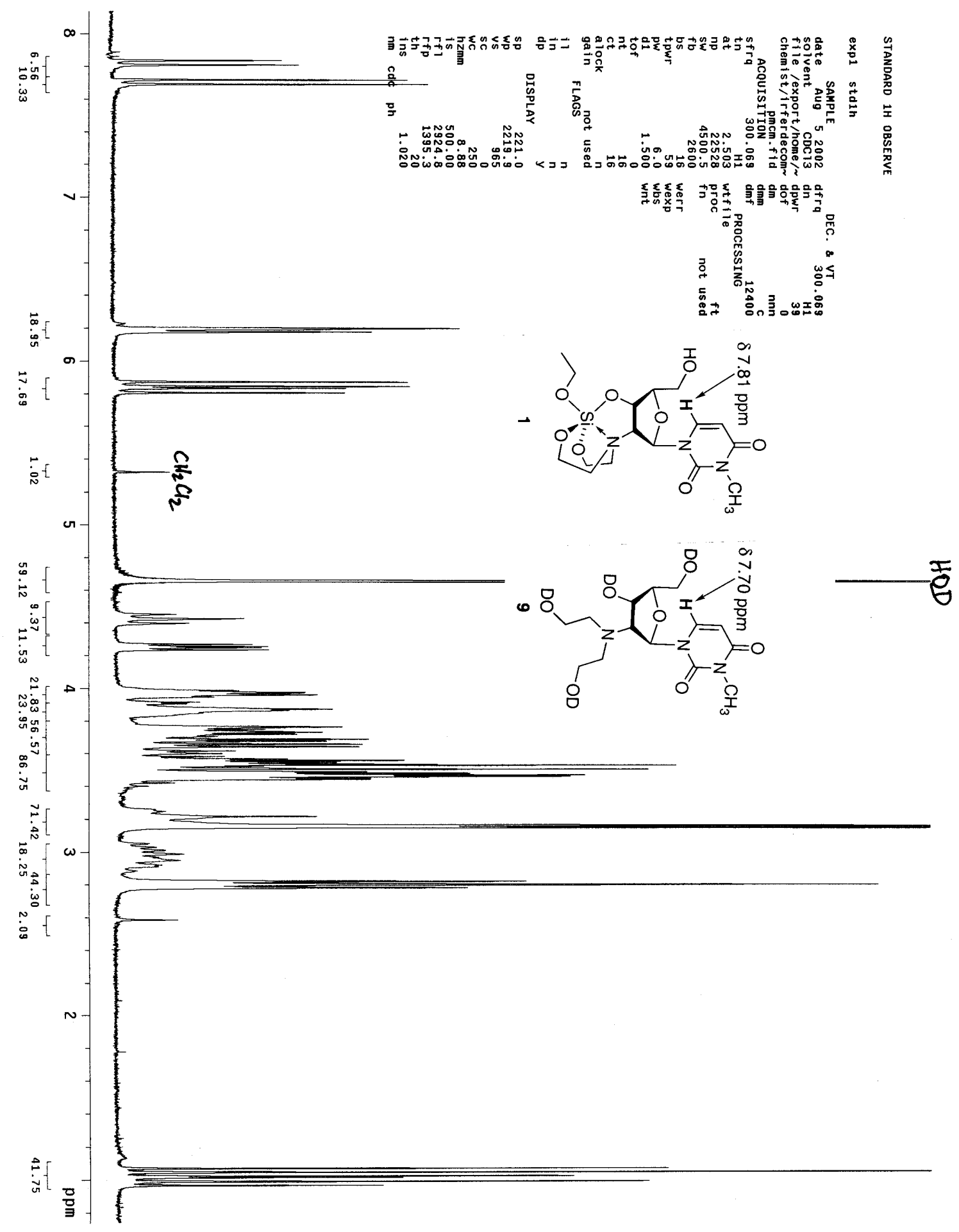




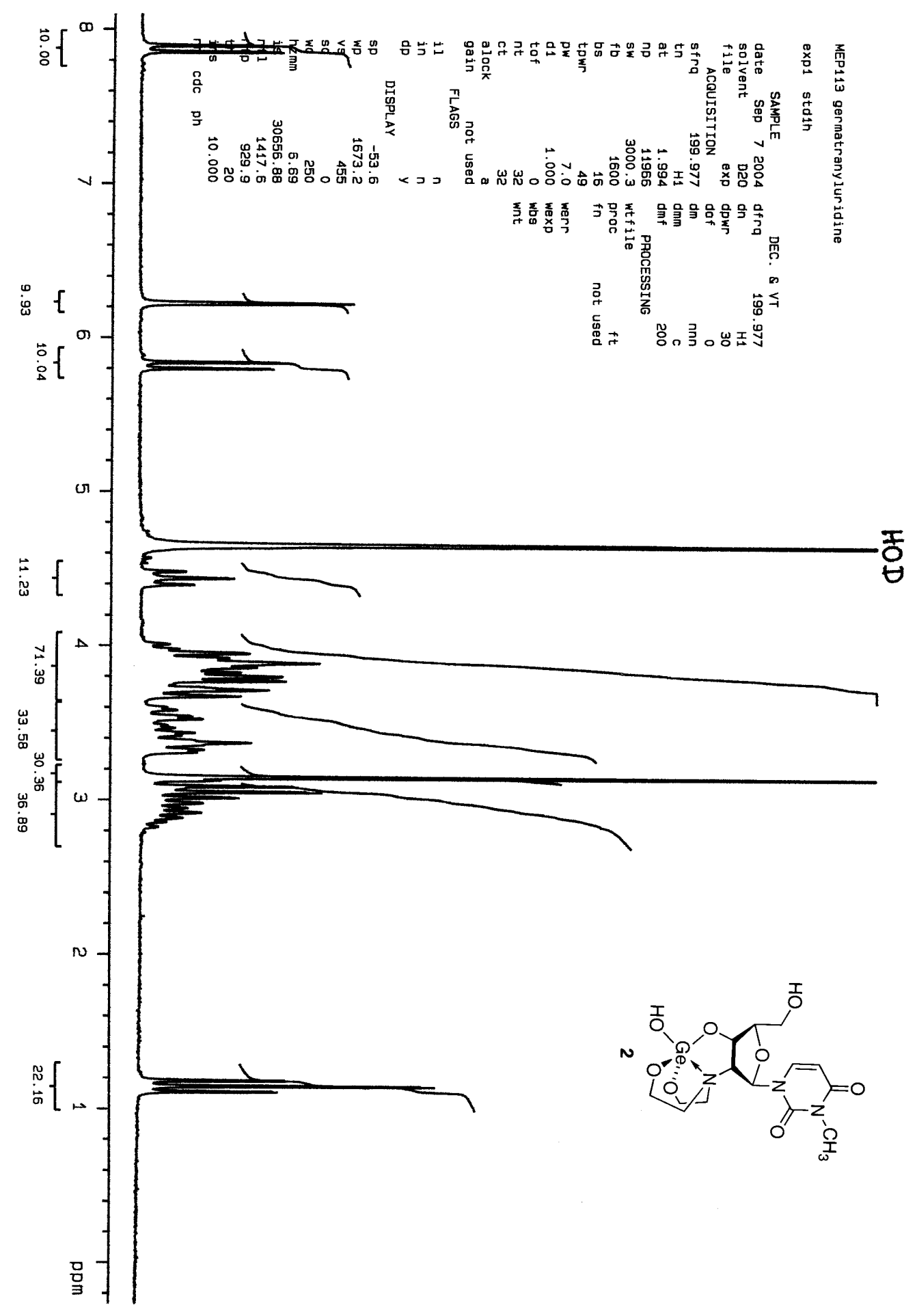




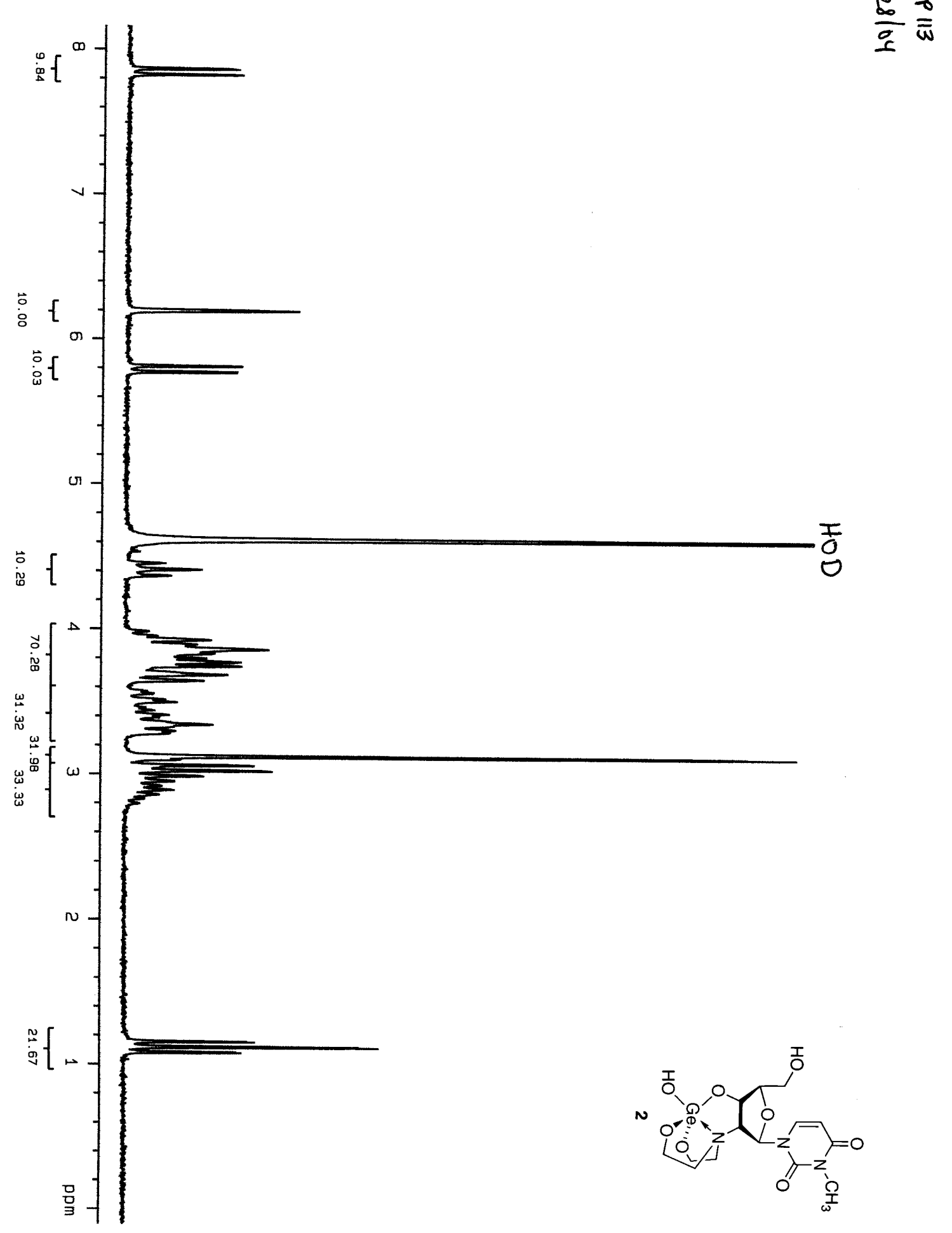




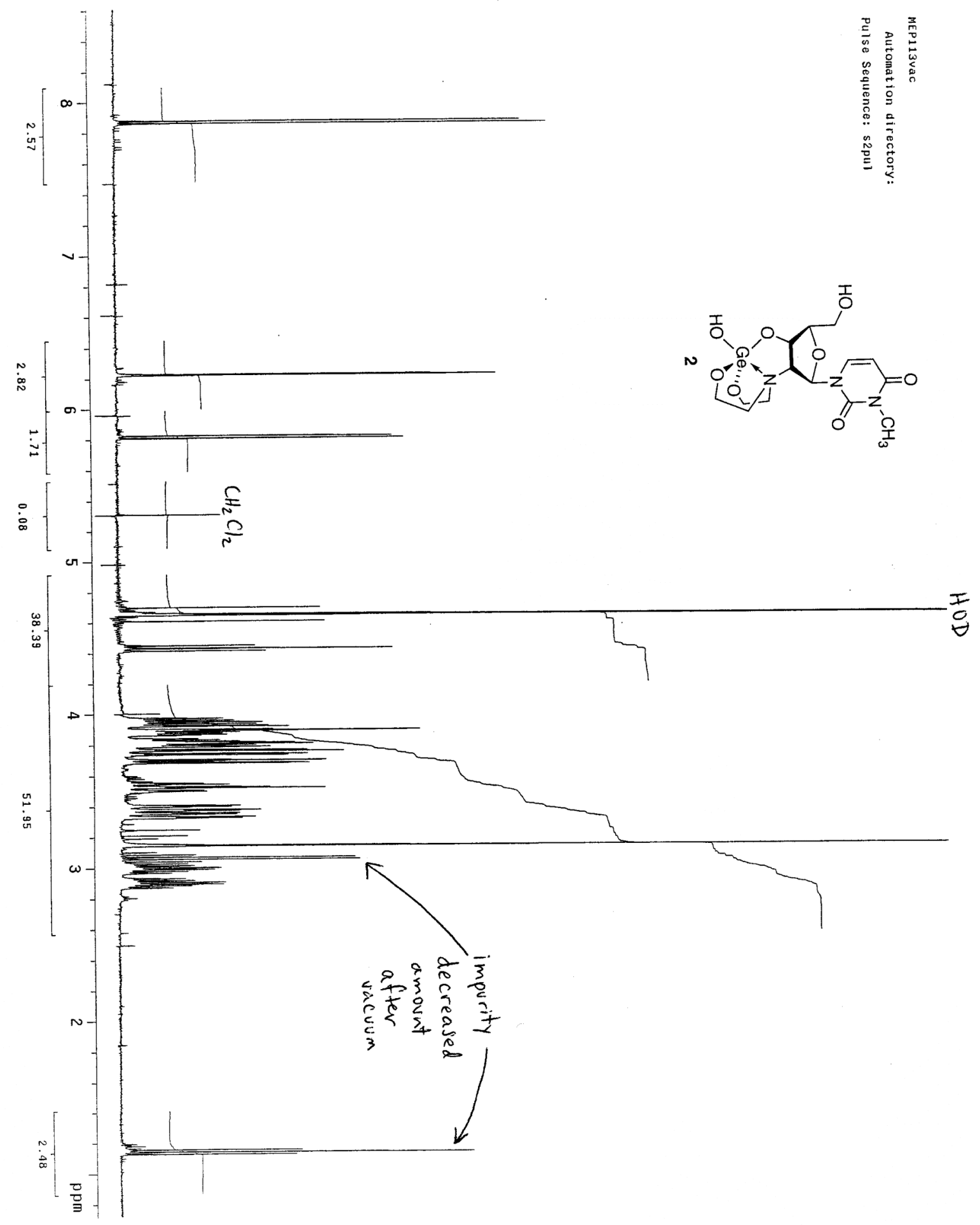

